\title{
Slavery in Charles Dickens' Novel Oliver Twist
}

\author{
Van Arlin Abas \\ English Literature Department \\ Universitas Muhammadiyah Gorontalo \\ Indonesia \\ Indah Wardaty Saud \\ English Literature Department \\ Universitas Muhammadiyah Gorontalo \\ Indonesia \\ indahsaud@umgo.ac.id

\section{Dahlia Husain} \\ English Literature Department \\ Universitas Muhammadiyah Gorontalo \\ Indonesia
}

Citation: Abas, V. A., Saud, I. W., \& Husain, D. (2020). Slavery in Charles Dickens' novel Oliver Twist. Notion: Journal of Linguistics, Literature, and Culture Vol 2(1), p. 51-57.

DOI: http://doi.org/10.12928/notion.v2i1.1110

\section{Article Info}

\section{Article History}

- Article Received

$29^{\text {th }}$ September 2019

- Article Accepted $2^{\text {nd }}$ May 2020

\section{Keywords}

Oliver twist

Slavery

Marxist approach
This research discusses the slavery experienced by the characters in the Oliver Twist novel. Those who have no family and no place to stay eventually become slaves who are forced to work for the benefit of the owner. They are treated as property and often get physical violence. This research aims to analyze the types of slavery that are reflected in Oliver Twist novel. This research using descriptive qualitative methods. Researchers used the Marxist approach and slavery theory to find the types of slavery contained in Oliver Twist novel. From the results of the analysis, it was found that there are 4 types of slavery in Oliver Twist novel, namely forced labor, sex slavery, child slavery and domestic servitude. 


\section{Abas, V. A., Saud, I. W., \& Husain, D. Slavery in Charles Dickens' novel Oliver Twist}

\section{INTRODUCTION}

Slavery is a social phenomenon that occurs in the social environment which experienced by the lowest class people. According to Brass[1] states that slavery is a socioeconomic system in which certain people (known as slaves) are deprived of personal freedom and forced to perform labor services. The formation of slavery communities begins from the relationship between people who have the means of production and the people who work. Until now the practice of slavery still occurs because of a conflict between the owners of the means of production and the workers (laborers). A slave was forced to work continuously by the owners of capital and is only given a salary just to be able to work and not die. This is in accordance with Marxism which the workers have been controlled by the owners of capital.

Marxism is an understanding that comes from Karl Marx's view. Marxism is a notion that aims to fight for the proletariat against the bourgeoisie. This flow of Marxism arose from a meeting of Karl Marx's places in the history of the class struggle, the birth of the labor movement[2]. The birth of Marxism was an early form of Marx's rejection of the capitalist system, in which Marx sees there has been a social divide practiced by European societies in which the clans of the nobility (bourgeoisie) have taken over the subordinate (labor). At that time the workers (proletarian) were forced to work only for the sake of a handful of nobles. In other words, the birth of Marxism is moving from the context of 19th century European industrial society, with all the injustices, human exploitation especially the lower classes/working class[3].

It was in Victorian Britain that Karl Marx became the first person to critically attack the privileges not just of a hereditary upper class, but of anyone whose labor output could not begin to cover their consumption of luxury. The Victorian era in the United Kingdom describes the period from 18371901 when Queen Victoria was on the throne. It was a time of rapid change and thanks to the Industrial Revolution saw the country evolve from a largely rural environment to an urban, industrialized one. Almost every aspect of life changed over the course of these sixty years including politics, attitudes to women, health, science and manufacturing[4].

Life for Victorian Children in Victorian times (1830 to 1900) is not like childhood in the world today. In Victorian times, the children who came from the upper classes (the wealthy) felt bored because of the constant urge to be decent and polite with little communication from parent to child. For poor Victorian children, life is very different. Poor children must work in public jobs so that their families can survive. Toys are nothing more than homemade dolls or wooden blocks. On the other hand, their family life is closer and more loving [5].

Oliver Twist was a novel by Charles Dickens which was published in 1838. Oliver twist appeared at Victorian era. In this era happened social change, economy and technology, Victorian novels seek to represent a large and comprehensive social world, with a variety of classes. Oliver Twist is written in the Victorian era became famous for employing children in factories. Child labor was a form of slavery which played an important role in the Industrial Revolution. They were forced to work in factories because they did not have enough money to live. Children work eight or twelve hours a day without insurance. so if they have an accident they have no help. During this period there was exploitation of children happened because children had given little wage and it is make employer did not take much money. The conditions of life for children were not good; there were not vaccines, and children were often sick, because they are working as adult[6].

This novel tells about orphan children who lived in unsanitary workhouses, children labor and slavery trade made illegal. The theme Oliver Twist novel is children are among other victims of Industrial Revolution. Dickens creates Oliver Twist as the major character in this novel. He is a young orphan and he live in the workhouse, but in there he gets treatment and punishment. The saddest thing about these images is that children are forced to work for cheap wages and treat as slavery. By knowing nothing about London, Oliver run away to London for more seven days by walking to get his fortune[7]. 
Oliver Twist describes how social condition force the major character did the horrible life and describes how slavery in this novel. So this the reason why the researcher interested to analyze this novel. This novel describes social condition that occur in England in 19th century. so, the researchers want to know about slavery that happen this novel. Oliver Twist novel guides the researcher to know deeper about the slavery. Slavery is very relevant to Marxist theory because it is related to economic, social and political systems. According to Suseno[8], Marxist was terminology relationship between social, political and economic concept. So slavery is more precisely studied using the Marxist approach. Marxism said that capitalist society leads to slavery and Marxists oppose slavery. For the reason above, researcher intends to conduct a study on Marxist approach entitled "Slavery in Charles Dickens's Novel "Oliver Twist".

\section{METHODOLOGY}

This research used descriptive qualitative method. Method in this research is qualitative method, through this research the researcher gives description clearly about slavery in Charles Dickens' Oliver Twist. According to Sugiyono[9], descriptive method used to describe or to analyze a result of research but not to use to make conclusion extensively. In analyzing slavery in Charles Dickens' Oliver Twist the researcher uses descriptive qualitative method. The researcher applied Marxist approach to analysis slavery in Charles Dickens' Oliver Twist.

\section{Marxist Approach}

According to Suseno[8], Marxist was terminology relationship between social, political and economic concept. The Marxist Approach was based on the theories of the philosopher Karl Marx. These theories were developed specifically to analyze how society functions where there was constant change. Marx developed a great theory relating to economic systems, social systems, and political systems. Followers of this theory were called Marxists. Marxism includes dialectical materialism and historical materialism and its application to social life. Marxists did not only emphasize the social role, but also they propagated, reflected and challenged the prevailing social norms, classes, and order.

\section{RESULT AND DISCUSSION}

\section{a. Forced labor}

Forced labor was person that forced to do against their will by someone through the use of violence. According to Boddy-Evans[10], forced labor was based on the use of violence to the laborer (or their family). Laborers cannot escape from enforced servitude.

Data 1:

The forced labor happened when Mr. Sowerberry will use Oliver because of his expression. Mr. Sowerberry was Oliver's master. Mr. Sowerberry tell to his wife that expression of melancholy in Oliver Twist will be interesting. This can be seen in following statement.

\section{It's only about young twist, my dear, said Mr. Sowerberry.}

A very good-looking boy, that, my dear. He need be, for he eats enough, observed the lady.

There's an expression of melancholy in his face, my dear, resumed Mr. Sowerberry, which is very interesting. He would make delightful mute, my love.

Mrs. Sowerberry looked up with an expression of considerable wonderment. (pg. 56)

The statement above showed the forced labor that was done by Mr. Sowerberry. Mr. Sowerberry as a master of Oliver Twist. He tells to his wife that Oliver is a very good-looking boy and there is an expression of melancholy in Oliver's face. Mr. Sowerberry will use the melancholy in Oliver's face because that expression is interesting and make a delightful mute. As a slave Oliver must do what his master ask to do without against. According to Lombardo[11], forced labor is a work given by someone forcibly to his or her will and forced laborers is treated as property. Oliver Twist is forced to be a delightful mute without reject what the master ordered.

\section{Data 2:}

Oliver no longer works at Mr Sowerberry's place and flees to London. After arrived in London, Oliver met one of the pickpockets' gang, Artful Dodger. 


\section{Abas, V. A., Saud, I. W., \& Husain, D. Slavery in Charles Dickens' novel Oliver Twist}

Oliver was brought to his gang leader. The leader of the pickpocket gang was called Fagin. Fagin employed his pupils as thieves. They were forced to do that work. Fagin ensures that his pupils does the work ordered by him. He said "I hope you 've been at work this morning, my dears?" And ask to Dodger what he got "What have you got, Dodger?". This can be seen in following statement.

Well, said the Jew, glancing slyly at Olive and addressing himself to the dodger, I bope you ve been at work this morning, my dears?

Hard, replied the Dodger.

As nails, added Chaley Bates.

Good boys, good boys! said the Jew. What have you got, Dodger?

A couple of pocket books, replied that young gentleman.

Lined?, inquired the jew, with eagerness.

Pretty well, replied the Dodger, producing two pocket-books; one green, and the other red. (pg. 102)

This is the proved that Dogder was employed as a pickpocket by Mr. Fagin. Dodger got a couple of pocket books. One green and the other red. He gave the loot to his master, Mr. Fagin. After that Dodger got some food. According to the International Labor Organization Forced Labor Convention[12], Forced or compulsory labor is The work or service that is given by someone where the person given the job does not offer himself voluntarily. Dodger stole at the will of his master. He never offered himself to work as a thief voluntarily. Dodger was forced to steal without being able to reject the request from his master.

\section{b. Bonded Labor}

Debt bondage describes slavery where someone is forcibly employed to pay off debt. Initially an agreement was made by employers and workers. However, the agreement is only beneficial for the employer. So that workers become slaves and cannot leave their jobs because of the initial agreement that has been made. The employer will continue to add additional costs so that the worker will continue to work but cannot pay the debt[11].

\section{Data 3:}

The researchers did not find the data about debt bondage in Oliver Twist Novel by Charles Dickens because the novel do not describe there is a debt bondage. Oliver, who works at Mr. Sowerberry's place, is not bound by any debt. Whenever, Oliver can go and leave the Mr. Sowerberry's place that is where he works. This is can be seen in following statement.

With the first ray of the light that struggled through the crevices in the shuttered, Oliver arose and again unbarred the door. One timed look around-one moment's paused of hesitation-he had closed it behind him, and was in the open street. He looks to the right and to the left, uncertain wither to fly. (pg. 82-83)

Hush, Dick! said Oliver, as the boy ran to the gate, and thrust his thin arm between the rails to greet him. Is anyone up?

Nobody but me, replied the child.

you mustn't say you saw me, Dick, said Oliver. I am running away. They beat and ill-use me, Dick; and I am going to seek my fortune, some along way off. I don't know where. How pale you are? (pg. 83-84)

The data above proved that there is no debt bondage in Oliver Twist novel. There is no an agreement between Oliver and Mr. Sowerberry. Oliver can leave Mr. Sowerberry's place whenever Oliver want to go. Oliver can run away from where he works because he is not bound by debt with his master. On the way Oliver stopped in front of a house. and met his friend named Dick. Oliver asks his friend if anyone has woken up. Oliver also told his friend not to tell anyone that his friend saw him. Oliver escaped from where he worked because his master beat him and treated him badly. He wanted to find his luck in a distant place. This proved that data contradict with theory of bonded labor according to Black[13], state that bonded labor is a form of debt bondage that occurs because someone has debt to another person and the worker cannot get out of the situation. 


\section{c. Sex Slavery}

Beside forced labor that happened in Oliver Twist novel by Charles Dickens there was sex slavery that describe in this novel. According to Lombardo[11], sex slavery is a woman, man or children are forced to do sexual act. Where they cannot stop to work or free to leave that work.

\section{Data 4:}

Conversation happen between Mr. Bumble and the stranger that named Monk in public-house. Mr. Bumble walked over to a strange young man who was none other than Monk. Monk is the nickname of the foreign man. Mr. Bumble is the current master of workhouse when the stranger asks Mr. Bumble. Monk gave two gold coins to his colleague, Mr. Bumble to get information. Monk began to tell the location and time specifically to Mr. Bumble. Then tell the life in that place. Female workers in the workhouse are employed as sex slaves. Where they gave birth to their children and then the child was raised by residents. This is the can be seen in following statement.

The scene, the workhouse.

Good!

And the time, night.

Yes.

And the place, the crasy bole, whenever it was, in which miserable drabs brought forth the life and health so often denied to themselves-gave birth to pulling children for the parish to rear; and hid their shame, rot 'em in the grave! (pg. 440)

From the data above showed the woman in the workhouse worked as a slave like the stranger man tell to Mr. Bumble how the situation in workhouse. To be able to survive they work under the control of the workhouse. Workhouse is a place where children or workers at work are in accordance with the authority of the place. In that place, even female workers have given birth to their children. This proves that they are employed as slaves as sex. Children generated from these jobs are then raised by residents. It is relevant with Lombardo's theory (2016), Sex slavery are exploited women, men or children in the commercial sex industry. Barry, in[14], said that sexual slavery is every situation where women or girls cannot change the immediate conditions of their existence where they are subject to sexual violence and exploitation. Where girls in workhouse was physically forced to do the work. The data was relevant too with International Labor Organization[12], the girls worked as laborers who became pregnant and gave birth to children at a very young age and had to take care of them while doing work that did not offer future prospects.

\section{d. Child Slavery}

According to Lombardo[11], Child slavery is children under 18 years old that employed through coercion and enslavement in hazardous work. Children are employed as a slave. Where children became a slave cause of their situation.

Data 5:

Mr. Sowerberry was in his shop. He was visited by the village secretary who was none other than $\mathrm{Mr}$. Bumble. Mr. Bumble came to the shop which was a coffin shop and gave Mr. Sowerberry a piece of paper and said the coffin and after that the village burial. After conveying this, the bumble master immediately left the shop. After the departure of the bumble master, Mr. Sowerberry calls on the Oliver Twist to leave immediately to carry out their work.

Well, said Mr. Sowerberry, taking up his hat, the sooner this job is done, the better. Noab, look after the shop. Oliver, put on your cap, and come with me. Oliver obeyed, and followed his master on his professional mission. (pg. 59)

Oliver works for Mr. Sowerberry who is his master. The master says that the sooner the job is finished, the better. His master said this to Oliver after being visited by the village secretary. $\mathrm{Mr}$. Sowerberry ordered Noah who was a child who worked in the same place with Oliver to look after the shop while Oliver would go with his master to work. Oliver has no choice but to follow what his master says. Oliver followed the orders of his master to follow his master. This of course will provide an advantage for Mr. Sowerberry. Because now he can use Oliver for his own sake. This is relevant to the 


\section{Abas, V. A., Saud, I. W., \& Husain, D. Slavery in Charles Dickens' novel Oliver Twist}

Anti-Slavery theory[15] that children are exploited for the benefit of others.

\section{Data 6:}

Oliver no longer works at Mr Sowerberry's place. He decided to leave the house of his master. Oliver fled to London and meet one of pickpocket gang. Fagin is a pickpocket gang leader who is the master of Oliver Twist after. Fagin provided his men with some money to spend because they had finished doing the work ordered by Fagin. This is can be seen in following statement.

There, my dear, said Fagin. That's a pleasant life, isn't it? They have gone out for the day.'

Have they done work, sir? Inquired Oliver.

Yes, said the Jew; that is, unless they should unexpectedly come across any, when they are out; and they won't neglect it, if they do, my dear, depend upon it. (pg. 106)

From the data above, it can be seen that besides Oliver which is used as child labor. There are several children employed. They were ordered to pick pockets by their master, Fagin. Oliver asked his master whether the children had finished doing their work. Because Oliver at that time did not know what kind of work his master gave the children. Fagin agreed to the question from Oliver. And connect the sentence with words if they accidentally meet the target on the road. This shows that the children were employed as pickpockets. this is relevant with Lombardo's theory[11], children who are under the age of 18 are employed through coercion or fraud. Children do dangerous work. Pickpocketing is a form of work that is dangerous for children. Especially children who are almost the same age as Oliver.

\section{e. Domestic Servitude}

Domestic servitude is a work that given to someone in a private home and people are employed must do what the employer order. According to AntiSlavery International[16], Domestic work is form of exploitation and working inside a private household with a lack of legal protection. The pay is often very low even some domestic workers may not be paid at all or only receive 'payment in kind' such as food or accommodation.
Data 7:

Oliver was working in a workhouse. Workhouse is a place where an orphan live and work. In workhouse, the children work start from six o'clock to pick oakum.

Well! You have come here to be educated, and thought a useful trade, said the red-faced gentleman in the high chair.

So you'll begin to pick oakum tomorrow morning at six o'clock, added the surly one in the white waistcoat. (pg.20)

The statements above showed when Oliver left the original place where he had lived. Oliver will now be brought by Mr. Bumble to a workhouse. After arriving at the Olivier's workhouse will be educated and taught useful skills. This is a work that must be done by children who live in the workhouse. Oliver will begin to pick oakum at six o'clock. As a child who works throughout the day Oliver does not have the opportunity to study in formal education. He spent his time working from 6 in the morning. In fact, he did not get a salary other than being fed. It is related with Lombardo's theory[11], domestic servitude is slaves who are forced to work in a private home. employers use coercion or fraud to control workers so they have no choice but to work continuously. Workhouse as a private home where Oliver will live and doing work. According to Anti-Slavery International[16], domestic servitude are slaves who are forced to work in private homes and lack legal protection. the wages earned are very low even not paid at all or only receive payments in kind such as food. Oliver just have some food as his wage after he work to pick oakum.

\section{CONCLUSION}

In Oliver Twist, novel by Charles Dickens, the researchers make a conclusion of what has been analyzed in the previous chapter. Oliver Twist novel by Charles Dickens illustrates the existence of slavery that occurred in the novel. Where slavery was analyzed using Crystal Lombardo's theory. From five types of slavery by Crystal Lombardo, it was four types of slavery found in Oliver Twist Novel by Charles 
Dickens. That are forced labor, sex slavery, child labor and domestic servitude.

\section{REFERENCES}

[1] Brass, T. \& van der Linden, M. (1998). Free and unfree labour: The debate continues. Berlin and Paris: Peter Lang AG.

[2] Syadali, A., dkk. (1997). Filsafat Umum. Bandung: CV. Pustaka Setia.

[3] Setiawan, T. B. (2016). Ekonomi Politik Pendekatan Marxisme. Retrieved June 01, 2018 at 09.56 from https://titobagussetiawan.wordpress.com/2016 /03/07/ekonomi-politik-pendekatan-marxism/

[4] McBeath, V. L. (2018). The Victorian era: England 1837-1901. Retrieved May 31, 2018 from https://valmcbeath.com/victorian-era-england1837-1901/\#.Ww-chvW4Vdg

[5] Price, P. (2012). Victorian children in Victorian times. Retrieved May 31, 2018 from https://victorianchildren.org/victorian-childrenin-victorian-times /

[6] Yuukyu, Wny. (2011). Exploitation of child and class social in Oliver Twist. Retrieved May30, 2018 from

http://kyuwenn.blogspot.com/2011/10/exploit ation-of-child-and-class-social.html

[7] Dickens, C. (2017). Oliver Twist. Jakarta: PT. Gramedia Pustaka Utama.

[8] Suseno, F. M. (2001). Pemikiran karl marx: dari sosialis utopis sampai ke perselisiban revisionism. Jakarta: PT. Gramedia Pustaka Utama.

[9] Sugiyono. (2012). Metode penelitian kuantitatif kualitatif dan R\&D. Bandung: Alfabeta.

[10]Boddy-Evans, A. (2017). Types of slavery in Africa. Retrieved August 16, 2018 at 13. 07 from https://www.thoughtco.com/types-of-slaveryin-africa-44542

[11]Lombardo, C. (2016). Five types of modern day slavery. Retrieved March 17, 2019 at 13.14 from http://visionlaunch.com/5-types-modern-dayslavery/

[12]ILO. (2004). Child labour: A textbook for university student. Geneva: The International Labor Office

[13]Black, K. (2003). What is bonded labor. Retrieved August $16^{\text {th }}, 2018$ at 13.30 from https://www.wisegeek.com/what-is-bondedlabor.htm\#didyouknowout

[14]Alfred. (2017). Slavery of the main character solomon northup in the 12 years a slave movie. Jurnal Ilmu Budaya, 1(3), p. 183-192

[15] Anti-Slavery. (2019). Child slavery. UK. Retrieved July 20, 2019 at 19.00 from https://www.antislavery.org/slaverytoday/child-slavery/

[16] Anti-Slavery. (2018). Domestic slavery. Retrieved March 08, 2019 from https://www.antislavery.org/slaverytoday/domestic-work-and-slavery/ 